\title{
Clio
}

Women, Gender, History

$40 \mid 2014$

Making Gender with Things

\section{Aurora of Arles, Queen of Dolls}

Aurore l'Arlésienne, reine des poupées

\section{Sylvie Sagnes}

Translator. Marian Rothstein

\section{OpenEdition}

\section{Journals}

Electronic version

URL: http://journals.openedition.org/cliowgh/718

DOI: $10.4000 /$ cliowgh. 718

ISSN: 2554-3822

Publisher

Belin

Electronic reference

Sylvie Sagnes, "Aurora of Arles, Queen of Dolls », Clio [Online], 40 | 2014, Online since 15 April 2015, connection on 22 April 2019. URL : http://journals.openedition.org/cliowgh/718 ; DOI : 10.4000/ cliowgh.718 


\section{Documents}

\section{Aurora of Arles, Queen of Dolls}

Sylvie SAGNES

This doll was born on December 25, 1999 in the town of Meynes. She was given by [her] godmother the seventeenth Queen of Arles, ${ }^{1}$ Aurora Guibaud, and Madame Marie-José Moreau, for the city of Arles' transition into the twenty-first century.

Bouen tous temps. Happiness and prosperity without end. Our ancestors exchanged these old Provençal good wishes when visiting each other on important feastdays, and at certain celebratory gatherings both public and private. ${ }^{2}$

Aurora, seventeenth Queen of Arles

Mme Moreau and her family

Gérard Blanc, mayor of Meynes.

These explanatory words on a document carrying the official stamp of the Meynes town hall note the Museon Arlaten's acquisition of a

1 The election of a queen of Arles was begun by the city's feastdays committee in 1930 on the hundredth anniversary of the birth of Frédéric Mistral [1830-1914), poet and champion of Provençal identity. During her reign, which today lasts for three years, the queen has the official role of "ambassador without embassy" for the city and more broadly for Provençal culture. See Gil 2008: 3. In her role as representative, she is assisted by maids-of-honour, candidates for future elections.

2 The Provençal expression, its translation, and its explanation were taken by the writers of the letter from Avril J.T., Dictionnaire provençal-français, Edouard Cartier, Art, 1839: 46. 
duly inventoried "hand-delivered gift", the doll "Aurora", in January 2000. This miniature Arlésienne was not the first of her kind to be included in the collections of the hundred-year-old museum, which by that time already contained over fifty such little figures. But the accompanying message, and the details supplied orally by the donor to help properly catalogue the item, distinguish "Aurora" from the crowd of her peers. The museum had only limited information about the others, confined to the materials and techniques used to make the dolls and their costumes, since they had entered its collection long ago, at a time when the need to document the provenance of such objects seemed of minor importance. The new acquisition also suggests a continuity in the costumes of the dolls, which the Museum of Ethnography had either not known about, or not felt responsible for recording. No doubt the temptation to consider these dolls as related to trivial tourist souvenirs set the tone for their reception, suggesting inauthenticity. And yet, everything about "Aurora" encourages a break with such an assumption: her dress made of entirely authentic elements ("silk woven in Baux-de Provence", "scarves and lace from the store $A$ l'Arlésienne, where women wishing to keep up local traditions of dress make their purchases, "vintage multicolored ribbons from antique shops", a cross from the Abbey of Frigolet), and her mission as an emblem of unchanging Provence across the centuries and even millennia.

It seems all the more necessary to re-examine "Aurora" and the dolls costumed in Arles, since once they are considered in a broader context, these little Arlésiennes turn out to be the exceptions that prove the rule. Almost everywhere else in France, souvenir dolls dressed in folk or historic costumes have in fact disappeared from shops aimed at tourists as they have from our private worlds. They resurface at garage sales, disheveled, scruffy, sometimes missing limbs. This is disconcerting when we consider that promotion of local identity has never been more enthusiastic than it is today. But recovery from this first reaction of surprise starts when we consider that these dolls are also collectors' objects and that their possession implies accumulation. As soon as they appeared in the Third Republic (1870 -1940) they were used to reinforce patriotic rhetoric at both 
local and national level: ${ }^{3}$ individually they illustrated France's diversity; collectively its unity. ${ }^{4}$ But if in the past the glorification of a locality implied all of France as well, this is no longer quite the case, following the crisis of national sentiment. One can see that such change has removed the main reason for a doll collection, and along with it, each of its parts. Under these circumstances, the longevity of the little Arlésiennes is all the more intriguing.

Costumed dolls in Arles and the surrounding area are still the product of craft workers recruited among the associations and institutions known as "la Maintenance". ${ }^{5}$ Most of the women who do the sewing have themselves worn or still wear the traditional dress of Arles and along with it, have a passion for local costumes worn during traditional local celebration, of which there are more and more, ${ }^{6}$ as well as at family ceremonies (marriages, baptisms, burials). When they were asked in semi-directed interviews conducted as part of an ethnological investigation in 2008, all the doll-makers voiced a concern with authenticity - the other side of which is the rejection of the cheap tourist souvenirs in vogue from the 1950s to the 1970s. "Those were very inaccurately costumed dolls," says Bernadette "[...] their costumes quickly constructed [...] by people with very limited acquaintance with authentic local dress." Another respondent, Jacques, thought them "disgusting" and "so ugly" that he began to construct some himself, before commissioning his mother to make them, and putting them on sale at his shop devoted to Provençal crafts. The common rule observed by all is faithful reproduction of

3 Thiesse 1997.

4 Koenig [1900] and 1909.

5 The name given to the set of institutions and associations dedicated to preserving Provencal language and tradition.

6 The major events are the Festival of gardiens [cowboys of the Camargue], the Queen's Ball, the Satin Race [bareback horse race whose winner is awarded a satin scarf- translators note, hereafter t.n.], bonfires on Saint John's day, la Pégoulade [a parade at the start of the bullfight season, t.n.], the queen's serenade, the costume festival, the cocarde d'or [a bullfight, t.n.], the santons market [Christmas crêche miniatures t.n.], the Ceremony giving the head dress associated with the regional costume to young girls, called Mireietos (little Mireilles) in reference to Mistral's poem. 
the local costume and its promotion. The little Arlésiennes are "dressed like the real ones":

Pins are put just where we put them [explains Agnès.] The under-scarf has five folds, three visible ones, two hidden ones, and over that there is the gimple and the front. And that is held in place by pins, everything is pinned.

The greatest proof of the sincerity of this accurate translation of tradition to the world of dolls is that they can be undressed, which implies the absence of any cheating like, for example, the use of glue:

I hand-sew the cloth, [Agnès continues] so if you want to undress the doll, l'ese [the bodice] is not attached to the body, it is separate. If you want to undress her, you can and then dress her differently.

The faithful reproduction of the costume has many other aspects, as, for example the choice of patterns suitable to the scale. The dolls' size may make the task easier for seamstresses who are aware of this, rejecting the miniatures and other very small dolls that now dominate the tourist trade.

Just the same, and like the earliest dolls dressed in historic and traditional costumes that appeared in the nineteenth century, the little Arlésiennes start from mass-manufactured dolls. The dressmakers have bought them, either in the toy department, like "Aurora", who was the plaything of Marie-Josée Moreau's daughter before being turned into an emblem, or in doll-collectors' shops. Rarely are artists' mannequins used. Having said this, to transpose a real costume to a doll is one thing, to do so using a pre-existing doll without having any control over its form is another. In fact, the greatest problem is not what one might expect, i.e. that most manufactured dolls are made in the shape of little girls. One might think that these dress-makers, having in mind the miniaturization of an adult dress, would reject such models preferring dolls of more adult proportions like Barbie. But for them, this is a misunderstanding of the problem. The obvious inadequacy of these doll-bodies to the costumes they will wear is not discussed, being swept aside by a counter-argument: we are in the realm of the Doll, and the Arlésienne, queen or not, must submit. Hair, on the other hand, its color, what it is made of, its length, poses greater problems. New techniques have been perfected to overcome 
them (the use of cold or tepid water, responding to materials), unless more radical measures are taken and the hair replaced. The shaven dolls are given hair made of goat mohair that lends itself better than other fibers to the sophisticated hairdo of the Arlésienne, which hides cardboard, combs, laces, clamps, and barrettes. When it has been curled and placed in symmetrical bands, topped with a tie or a ribbon or braided cord, the doll's hair helps create her identity as a Arlésienne and this image is more important than body-shape.

If the inventory card says nothing about "Aurora's" hairdo, it nonetheless corroborates the concern with exact details that is manifest in the dress of these tiny Arlésiennes. Even more important than the demands of authenticity, the doll presented to the museum shows another characteristic of these objects: their place in an economy of giftexchanges - for most of these miniatures were exchanged. The history of these dolls, as it is told in Arles, stresses this detail: before they became ethnological objects, these dolls were associated with marriages, dressed in wedding dresses with trains, and given to young brides by the seamstress responsible for making them, later to be preserved and exhibited in the conjugal bedroom, like wedding bouquets or headdresses. Although the twenty-first century is not a period especially predisposed to such rites since there are now fewer marriages than ever before, this tradition is re-emerging before our eyes using other circumstances as a pretext, starting with major life-moments like wearing traditional costume for the first time. But not only that:

When I was elected [lady in waiting to the queen of Arles], my motherin-law made a doll dressed as I was. As I never married, sometime after I was elected she gave me a doll in a glass case dressed exactly as I was on the day of the coronation, in the Roman theater.

The little Arlésiennes also appear in everyday life, and may be symbols of particular affection.

When I need to give a gift [Jeanne comments] [...] I make handmade presents, but to carefully chosen people. I would not give an Arlésienne doll to just anyone.

In these exchanges, the completed miniature is not the sole medium of exchange. The elements composing her also come from the other direction, toward the doll's creator. 
Ah, well, often in my mailbox I find bits of lace, I find pins, I find ... People know, and to please me ...

Bernadette explains. She likes to show, in addition to the tiny gloves and the little basket especially made for her, a miniature page (a clip to hold the skirt up) given her by the great-grand-daughter of Léo Lelée whom she mentored in costume making:

One day, at a flea-market, she found this page and gave it to me to thank me for my advice. [...] We have very strong ties, and so I was delighted to receive this little page that works just like a real one.

Whether for important or minor occasions, whether as splendid gifts or these little trifles, such "friendship offerings" as Isabelle so nicely puts it, trace the back and forth of reciprocity, the contours of a family of choice, united not so much by the love of dolls as by a passion for costume and tradition. In any case, that is what is suggested by those giving scraps of cloth or lace to Jeanne:

People come with a bag and say, "Oh well, we don't have any children to leave things to, you know". Or "Our children don't care about this sort of thing. They'll throw it out or sell it.

By turns giver or receiver, the doll-maker is part of a logic of transmission which reaches beyond her. More or less consciously, more or less deliberately, ties are formed, a kind of interdependence is created. "Something happens" as Laurence perceives it.

This "something", moreover, causes the question of money to be, if not inappropriate, at least problematic. What is given and received is outside of the realm of merchandise that might have a price tag. To price, to sell, to ask for payment is not a simple matter. Still less to live from one's craft. Those who, in spite of this, decide to sell what they make, need to seek out a compromise. Agnès feels that it is important that "it be accessible so that it gets passed on".

When people tell me "I get paid to arrange the hairdos [of the Arlésienne dolls]", 8 I don't like it, because what is important is to keep up the tradition, and that should not become a money-making proposition.

\footnotetext{
7 The illustrator Léo Lelée (1872-1947) is considered the "painter of the women of Arles".

8 Wearing the costume implies skills for which beginners who have not yet developed them, call for help from experts, costume makers or hairdressers.
} 
Would naming a fair price for the costume solve this problem? Is the question of who might own the dolls not still an issue? If these objects were simply commercially available to tourists, French people, and foreign visitors, wouldn't the money still imperil the more or less closed society the doll is part of? The fact that no one discusses this question tends to prove that the Other is in fact more needed than it might seem for the affirmation of an identity. Under the eyes of the Other, a sense of self is forged and affirmed. Nothing then keeps these dolls, like that other ambassador, the Queen of Arles, from going outside the borders of the kingdom of the Arlésienne, toward a world outside and elsewhere, a mirror in which the qualities unique to Arles are reflected reassuringly for those inside.

Although assigned to a permanent spot, "Aurora" owes it to the heritage status bestowed on her by her place in the museum, i.e. her status as a piece of collective property, to take beyond the guardians of tradition the message about what is typical of the locality. Some of these little Arlésiennes represent more than just a stereotypical inhabitant of Arles, starting with "Aurora", the miniature double of the Queen to whom she owes her name; or "Henriette", given to Nikita Khrushchev in 1960, who was a replica of Henriette Bon, the ruling queen that year. But beyond the flexible limits within which the dolls constantly evolve, there are dolls that are portraits kept by their creators. Made corresponding to a living model, they express particular recognition and connection. Bernadette made such a doll in the image of her maternal grandmother:

Thanks to her, I habitually wore the local costume on holidays; she was really the person who made this appealing to me, even though she did not dress that way herself after the Second World War. [...] And so, she was the one who advised me, all that. And when she died, I said to myself: "I must ..." So then I commissioned an artist in the Var to make a doll $[\ldots]$ with blue eyes, and we found some goat mohair the same color as my grandmother's hair and then I dressed her in the style she liked, and it was all done.

Although she chose other ways of paying tribute:

I still continue to wear authentic costumes. They are mended, they smell of perspiration, all sorts of things, but I feel I am lucky, each time I go out, to bring all these souls along with me. 
Jeanne nonetheless created two copies of a single marriage doll, one for the bride, her sister-in-law, one for herself:

My sister-in-law, there, got married in local costume, she is up there [on the shelf]. It is a modern doll because [...] my sister-in-law is a modern woman.

This doll all dressed in white, testifies to the affection between the two women, and in the contrast between it and the doll facing it carries another message:

On the other hand, that one over there has a traditional look. She has a traditional face. And she is blonde!

Blonde like Jeanne herself, who likes to say that she has a nineteenthcentury look. In this case, the doll is a self-portrait, part of a selfaffirmation of which the group of dolls is a powerful reflection.

Taken as a whole, this series of dolls, each one illustrating a point in the history of costume in Arles, demonstrates a remarkable retrospective of the evolution of the full-size local costume. Considering themselves a bit reborsièra [feisty], ${ }^{9}$ the women of Arles aspire to "move to the other side of the line", that is, to work around the costume rules without infringing them too much. In the last few decades, the narrow path of compromise has led them to seek novelty elements, not in current fashion or in individual creativity, but in a less iconoclastic way, to look at developments from before the traditionally accepted reference period, i.e. the last few decades of the nineteenth century, the period of the final evolution of the costume, when according to Mistral it reached perfection from the point of view of harmony, delicacy, simplicity, and elegance, and thus ideally displayed the genius of the Provençal people. Magali and Odile Pascal, mother and daughter, personify better than most this recent turn to the "future perfect" of the costume where they are generally considered to be pioneers. The three huge volumes resulting from their research ${ }^{10}$ have been so well received as to eclipse the work of those who dress the dolls. It is an error to consider this work as a

9 The Occitan word reborsièra means annoying, crabby, from rebors, backward, against the stream of expectations.

10 Pascal 1992, 2001 and 2007. 
mere transposition in reduced scale of the scholarship of the Pascals. The dolls bear a separate interpretation, with its own history. Leaving Magali and Odile with the difficult task of skimming antique stores to continue to add to their collection and perfect their knowledge of these costumes, our dressmakers look instead in family closets and chests. The relics (remnants of cloth and old photos) that they find there feed their personal research, which in turn gives rise to the "writing of the hand", that is, dressing the dolls. Whatever turn it takes, the restoration of the costume's past is no more accidental than the variations in the costume inspired by it. Considered on the scale of the individual, they are a way of marking singularity: "Little details are what make the Arlésienne, we do not want to be like the others", Agnès declares, before adding that "the doll allows me to go further in the sense of saying: she is unique". In this way, the gallery of historical dolls sets before us that improbable Arlésienne that women dream of being, without daring to do so in "real life".

Even more than wearing the costume oneself, dressing the doll is part of a process of deviation, since it allows each seamstress individual expression under cover of the customary code of the local costume ("Arlesianism"). The costume of Arles lends itself in two ways to this association of intentions: not only can it be modulated, even if only tiny variations are permitted, but it is also becoming. At the same time, the exceptional status of the Arlésienne dolls underlines the problem encountered elsewhere of bringing together regional costume (dolls included), and present-day individualism. Failing to admit of variations or to function in terms of the group, other regional costumes are limited to museums or a self-conscious folk tradition. And with them, the dolls take their leave. Having said this, in Arles itself, one would look in vain for a male doll in the local costume - which in fact has nothing specifically local - or dressed as a gardian (traditional cowboy). The men of Arles in general are no less controlled by injunctions to be themselves than the women, but coquetry, the form of distinguishing oneself that is based on appearances, is more foreign to them, as are the creativity and dressmaking skills it is based on. The undivided triumph of the Arlésienne in all its forms shows us how, responding to individualism, fashion, 
even local fashion, remains a female domain, going so far as to make local identity a feminine phenomenon.

Translated by Marian ROTHSTEIN

\section{Bibliography}

GIL, Michèle, 2008. Histoire des Reines d'Arles de 1930 à nos jours. Saint-Rémy-deProvence: Equinoxe.

Koenig, Marie, [1900]. Poupées et légendes de France. Paris: Librairie centrale des BeauxArts.

- 1909. Musée de poupées. Paris: Hachette.

PASCAL, Magali et Odile, 1992, 2001 et 2007. Histoire du costume d'Arles, 3 volumes : 1. Les formes sous l'Ancien-Régime, 2: Néoclassicisme et romantisme, 3: Le temps des crinolines. Arles: Publication by the authors.

THIESSE, Anne-Marie, 1997. Ils Apprenaient la France: l'exaltation des régions dans le discours patriotique. Paris: Éditions de la Maison des sciences de l'homme. 


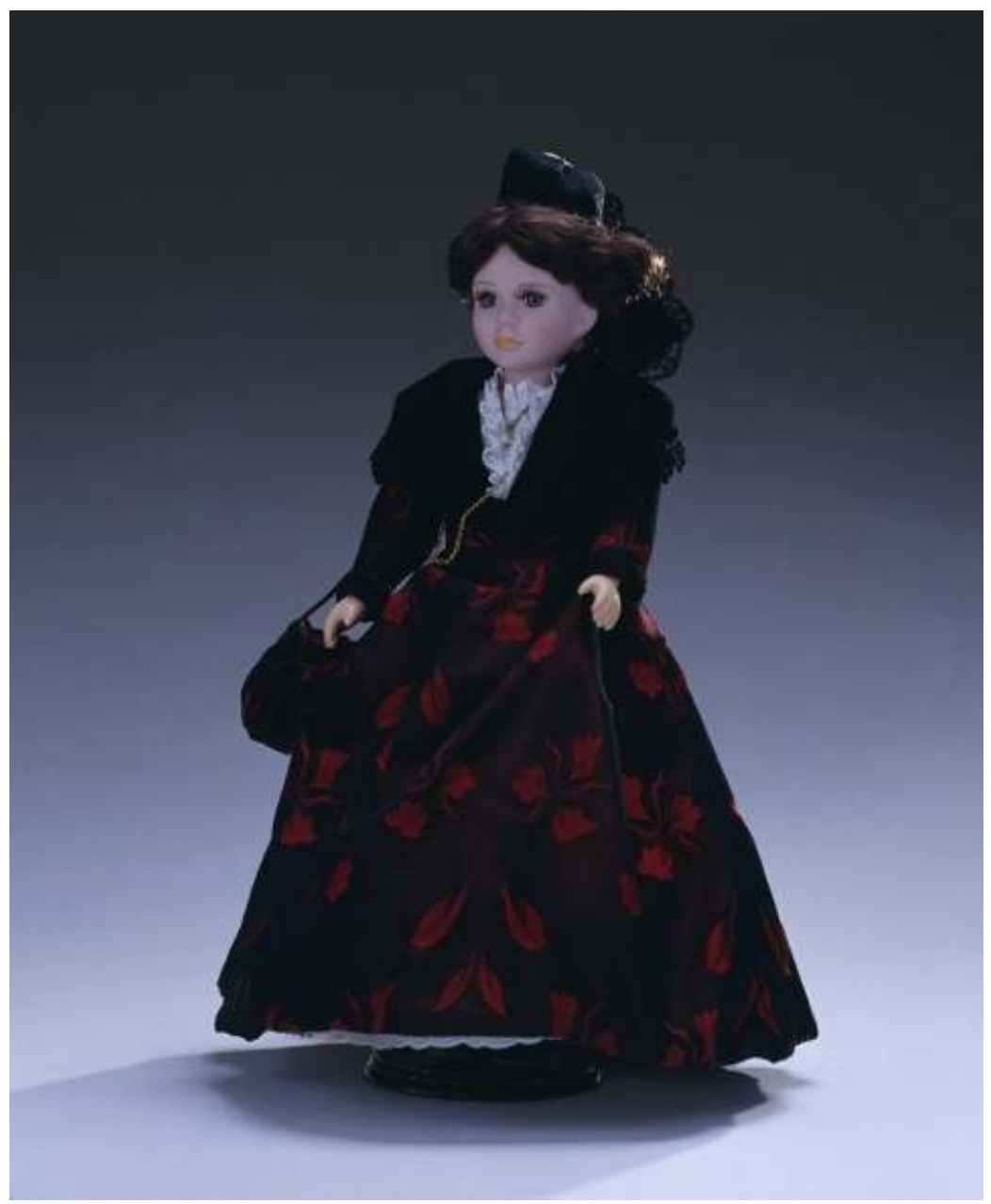

The doll « Aurore », 1999 (Collection of the Museon Arlaten, departemental museum of ethnography, Arles. Photo, J.L. Maby). 